Saudi Journal of Business and Management Studies Abbreviated Key Title: Saudi J Bus Manag Stud ISSN 2415-6663 (Print) |ISSN 2415-6671 (Online) Scholars Middle East Publishers, Dubai, United Arab Emirates Journal homepage: https://saudijournals.com/sjbms

\title{
The Effect of the Board of Commissioner Activities, Free Cash Flow, Institutional Ownership, Leverage and Company Sizes on Profit Management of Transportation Companies in Indonesia Stock Exchange (Bei)
}

\author{
Aisyah $^{1 *}$, Prof. Wiwik Utami, Ak. MS., $\mathrm{CA}^{2}$ \\ Mercu Buana Univesity Jakarta
}

DOI: $10.36348 /$ sjbms.2020.v05i02.003

| Received: 01.02.2020 | Accepted: 12.02.2020 | Published: 20.02.2020

*Corresponding author: Aisyah

\section{Abstract}

This research was conducted to examine the effect of commissioner activities, free cash flow, institutional ownership, leverage and company sizes on profit management of transportation companies in indonesia stock exchange (BEI). where the sample is a transportation company on the Indonesian stock exchange. The sampling technique used was purposive sampling. the number of samples based on transportation companies in the Indonesia Stock Exchange (IDX) is 34 , but 4 companies are not delisted and 30 companies are processed to conduct research. The research technique used is the classic assumption test, normality test, autocorrelation test, heteroscedasticity test, multicollinearity test, coefficient of determination, $\mathrm{T}$ test, and $\mathrm{F}$ test. This study uses independent and dependent variables. The variable results of the board of commissioners do not affect earnings management, free cash flow does not affect earnings management, institutional ownership affects earnings management, leverage does not affect earnings management, and company size influences earnings management.

Keywords: board of commissioner activities, free cash flow, institutional ownership, leverage, company sizes, profit management.

Copyright @ 2020: This is an open-access article distributed under the terms of the Creative Commons Attribution license which permits unrestricted use, distribution, and reproduction in any medium for non-commercial use (NonCommercial, or CC-BY-NC) provided the original author and source are credited.

\section{INTRODUCTION}

The company manager is the party that manages the company that directly knows the company's internal information through shareholders. As a manager, the manager is obliged to provide information about the company to the owner. This information about company finances and other information that is useful for external companies. According to PSAK No. 1 of 2009, one of the information presented in the financial statements includes: Assets, Liabilities, Equity, Income and Expenses including funds and contributions from the owner in his capacity as owner in making economic decisions is profit. Earnings information is used as a basis for predicting the company's performance and earnings in the future.
Conceptually, the company does not only gain profits (returns) in its operations process, but also must receive profits (risks) that may arise from its business activities. The higher the profit expected by the company, the higher the profit that must be borne. Or conversely, the higher the challenges that must be borne by the company, the higher the benefits to be gained. Therefore, by becoming a public company, the owner no longer thinks about his own interests. Risks will be shared with other shareholders, the ownership obtained must also be shared with other shareholders. Therefore trying to sell a portion of this ownership is in fact thinking of the old owner to distribute the company's risk to other parties. 
The company must provide a prospectus containing financial and non-financial information about the value and conditions of the company at the time of the Initial Public Offering. Financial statements, cash flow statements, cash flow statements, and an explanation of the financial statements. While nonfinancial information contains information about underwriters, independent auditors, legal consultants, the value of the stock offer, the percentage of shares offered, the old company, and other supporting information.

The information in this prospectus will provide an overview of conditions, economic prospects, investment plans, as well as forecasts of earnings and dividends needed as a basis for making decisions about finances and the value of shares offered by the company. Information needed by investors to determine, determine and make a decision on what the company deserves is chosen as the place to install the funds. At the time of the prospectus IPO was the only source of information in the process of this initial public offering because besides the prospectus there were almost no other sources of information available to investors. As a closed company whose ownership is approved, controlled by a certain family or group, then there is a public media that contains the company's values and requirements before going public.

\section{CHAPTER II}

\section{LITERATURE REVIEW，FRAMEWORK FOR THINKING AND HYPOTHESES}

\section{LITERATURE REVIEW Agency Theory}

Anthony, Govindarajan [1] agency relations exist when one party hires another party to perform a service, the principal delegates the authority to make decisions to the agent. The principal acts as a provider of resources and funds used by management. The management is fully responsible for the processing of resources and funds in order to meet the interests of the principal. Principals monitor the performance of agents through performance and financial reports submitted by management. Each party has rights and responsibilities in management and each party must be committed to respecting and respecting the rights and authority of other parties, and not allowed to intervene in the rights and obligations of other parties.

Agency theory assumes that all individuals act in their own interests. Agencies are assumed to receive satisfaction not only from financial compensation but also from the additions seen in an agency's relationship, such as more free time, attractive working conditions and flexible working hours. While the principal, is assumed to only be interested in the financial returns obtained from their investment in the company. The agency relationship between owners and managers of this company should produce a symbiotic relationship of mutualism that can benefit all parties, especially if each party exercises its rights and obligations responsibly.

\section{Positive Accounting Theory}

This research on earnings management practices is based on Positive Accounting Theory, which is a theory whose purpose is to describe and explain why accounting practices reach the form they are in now and why they can occur. This theory provides consideration in explaining phenomena that are currently happening but have not been documented [1]. One accounting practice that is attempting to be observed (explained) in this study is the phenomenon of earnings management.

\section{Information asymmetry}

Managers as managers of the company know more about internal information 14 and prospects for the company in the future than shareholders. Therefore as a manager, the manager is obliged to give a signal about the condition of the company to the owner. The signal given can be done through the disclosure of accounting information such as financial statements. The financial statements are intended for use by various parties, including the management of the company itself. But most concerned with financial statements are actually external users (outside management). The financial statements are important for external users especially because this group is in the most uncertain conditions [2]. Internal users (management) have direct contact with the entity or company and are aware of significant events that occur, so that the level of dependence on accounting information is not as great as external users. This situation will trigger the emergence of a condition called information asymmetry (information asymmetry), which is a condition in which there is an imbalance in information acquisition between management as a provider of information (prepaper) with the shareholders and stakeholders in general as information users (users).

\section{Leverage}

A company makes financial statements as information in decision making and is used as a measurement of company performance. Through financial ratio analysis we can understand the picture of a company's ability to fulfill its obligations in paying debts on time [3]. Kasmir [4] suggests the definition of leverage ratio is as follows

"Leverage ratio is the ratio used to measure the extent to which a company's assets are financed with debt"

Agus Harjito and Martono [5 leverage ratio is leverage, which is a ratio that measures how many companies use funds from debt (loans). Marcus Bob Sabran [6] leverage ratio measures how much financial leverage is borne by the company, because debt 
increases returns for shareholders in good times and reduces in bad times, the debt is said to create financial leverage. Irham Fahmi [4] leverage ratio is a measure of how much a company is financed with debt, from this understanding the researchers conclude that the understanding of leverage ratio is a ratio used to measure how much a company's assets are financed with debt.

\section{Activities of the Board of Commissioners}

Corporate governance is a tool that can reduce agency problems in a company [7]. Agency problem is something that will arise with the interaction or relationship between the principal and agent where the principal gives power to the agent to make decisions, with this relationship, there will be costs called the agency cost. Agency cost is the sum of monitoring costs by the principal, bonding costs from agents, and residual losses. Agency cost will also arise if there is a relationship of 2 or more people even though there is no clear principal-agent relationship. This agency cost not only can arise in non-bank companies but also can arise in the form of bank companies. With the emergence of agency costs, many companies have implemented good corporate governance to reduce agency costs [7]. The implementation of good corporate governance itself, there are some basic principles that are regulated in legislation in Indonesia. As quoted in the General Guidelines for Good Corporate Governance in Indonesia [8] by the National Committee on Governance Policy,

\section{Transparency}

To maintain objectivity, companies must be willing to provide information that is relevant and easily accessible to stakeholders such as shareholders, or potential investors. The company must try to comply with all applicable regulations and must be able to take the initiative in disclosing what is needed by investors, both in terms of information or financial statements and that need to be provided for the sake of decision making.

\section{Accountability}

The company must be able to account for its performance transparently and fairly. Therefore, the company must be managed properly, measured, and in accordance with the interests of the company. It also must consider the interests of others involved in the company. This accountability is a requirement that the company can achieve sustainable performance.

\section{Responsibility}

Companies must comply with applicable regulations and carry out responsibilities to the environment, social, and society. This was done in order to create long-term relationships with the whole community and gain recognition about the implementation of good corporate governance.

\section{Independence}

The implementation of corporate governance is going well, it requires the principle of independence to regulate each organ of the company so that it can run alone so that it does not dominate or be intervened by other parties. It can also support efficiency in company performance.

\section{Fairness and Equality}

In carrying out activities, companies must pay attention to the interests of shareholders both minority and majority. In a company all are considered the same and have the same rights and obligations in supporting the progress of the company later and to encourage the company's performance to improve.

\section{Institutional Ownership}

Institutional ownership is one of the factors that can affect company performance $[9,10]$. Institutional ownership will encourage more optimal oversight of management performance, because ownership of shares represents a source of power that can be used to support or vice versa management performance. According to Juniarti and Sentosa [11] in Yeterina and Shella [12] the definition of institutional ownership is Institutional ownership is the percentage of company ownership owned by institutional investors such as government, investment companies, banks, insurance companies and ownership of other institutions and companies. Whereas institutional ownership proposed by Riska Maliana [7] is a shareholder of institutions such as banks, insurance institutions, investment companies and other institutions, in relation to the monitoring function, institutional investors are believed to have the ability to monitor management actions better than individual investors. The strict supervision carried out by institutional investors is very dependent on the size of the investors carried out. The greater ownership by financial institutions to oversee management and consequently will provide greater impetus to optimize the value of the company so that company performance will also increase. Riska Maliana [13] institutional ownership can be measured by the number of share presentations owned by the institution.

\section{Free Cash Flow}

Companies with high free cash flow (high free cash flow) will have greater opportunities for earnings management, because the company is indicated to face a bigger agency problem [14]. Previous studies have shown that companies with high free cash flow surpluses also tend to practice earnings management by increasing reported earnings to cover managers' actions that are not optimal in utilizing company assets. White et al. [2] revealed that the greater the free cash flow available in a company, the healthier the company is because it has cash available for growth, debt payments, and dividends. Free cash flow is an important determinant in determining company value, so company managers are more focused on efforts to improve free 
cash flow [8]. In this study Free Cash Flow is measured by the total operating cash flow minus the cash flow from capital expenditure activities. This value will indicate the amount of free cash flow of the company for one year.

\section{Company Size}

Company size is a scale where the size of the company can be classified according to various ways, including og total assets, log total sales, market capitalization. Suwito and Herawaty [14] company size is divided into 3 categories, namely large companies, medium-size companies and small firms. There are various proxies that are usually used to represent company size, namely the number of employees, total assets, total sales, and market capitalization. Company scale is a measure used to reflect the size of the company based on total company assets [1]. Ghozali [15] revealed that the assessment of company size can use a benchmark of total assets. In this study, researchers used a total asset proxy; this is intended to reduce excess data fluctuations. If the total value of assets is directly used just like that then the value of the variable will be very large, billion and even trillion. Because the company's total assets are of great value, this can be simplified by transforming them into natural logarithms, without changing the proportion of their true origin.

\section{Profit Management}

Performance analysis of financial institutions, especially commercial banks, can be done from year to year, using financial ratios to provide information about financial performance, so that bank performance can be seen through assets, revenue, profit, market value, and the relationship of various financial ratios. so that it can show the bank's performance. Profitability is the ability of banks to get revenue and profit within a certain period using labor, assets and capital [16]. Profitability or profitability can be measured using gross profit margin, net profit margin return on equity capital, return on assets, and return on specific assets [17]. Profitability can also be measured using interest margin, net margin, and asset utilization, return on assets, leverage multiplier and return on capital [18]. Profitability ratios are intended to measure the profitability of using company assets. To analyze the financial condition and performance of a company, financial analysis requires a guide and a measure. Guidelines that are often used are ratios or indexes that connect two financial data. Analysis and interpretation of various ratios depends on the experience and ability of analysts in understanding the financial condition and performance of a company and will be better than the data analysis results themselves. One form of use of financial ratios is trend analysis.

\section{Framework for Thinking}

The framework of thought is a temporary explanation of the symptoms that are the object of the problem of the relationship between variables namely the independent variable and the dependent variable that is composed of various theories that have been described [19].

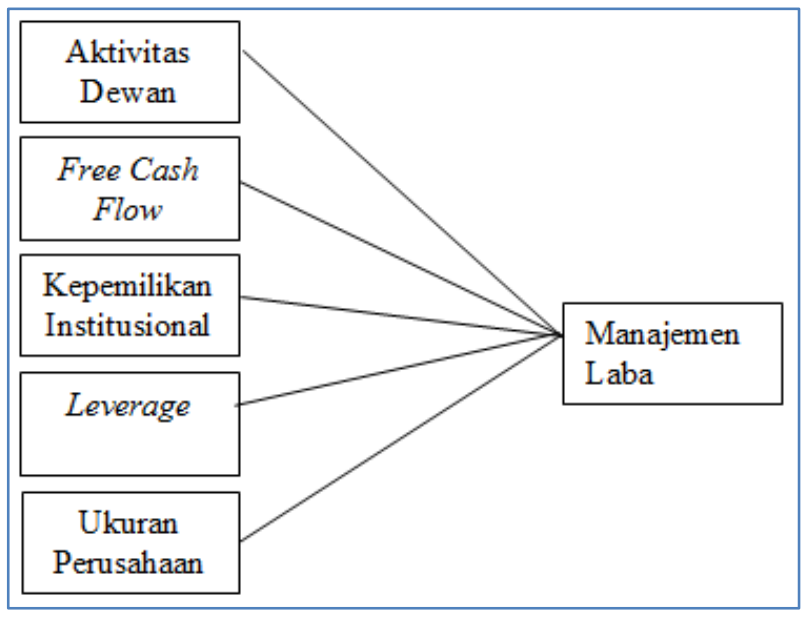

\section{HYPOTHESIS}

Based on the background, problem formulation, research objectives, as well as the description above, the researcher formulates the hypothesis as follows:

\section{Relationship between the Board of Commissioners' Activities and Profit Management}

Board of Commissioners' meetings are important in determining the effectiveness of the Board of Commissioners in carrying out supervision and control. Board of Commissioners meetings are a medium of communication and coordination between members of the board of commissioners in carrying out their duties as supervisors of management. Chen et al. [20] states that councils that hold meetings more often can reduce the likelihood of fraud, because regular meetings allow the board to identify and resolve potential problems, especially those related to the quality of financial reporting. 
H1: There is an influence of the activities of the board of commissioners on earnings management

\section{The Relationship of Free Cash Flow to Profit Management}

White et al. [2] revealed that the greater the free cash flow available in a company, the healthier the company is because it has cash available for growth, debt payments, and dividends. It can also be interpreted that the smaller the FCF value a company has, the company can be categorized as being more unhealthy. The results of research by Isnawati [11] which states that FCF has a significant negative effect on earnings management, while Kangarluei et al. [5] provide other evidence that the size of the FCF value of a company does not have a significant influence on the possibility of earnings management.

H2: There is an influence of Free Cash Flow with Profit Management

\section{Relationship of Institutional Ownership to Profit Management}

Ownership of a company can consist of institutional ownership or individual ownership. Or mix the two with a certain proportion. Institutional investors have several advantages compared to individual investors, including institutional investors who have more resources than individual investors to obtain information. Institutional investors have professionalism in analyzing information, so they can test the level of information reliability. Institutional investors, in general, have stronger business realities with management. Institutional investors have a strong motivation to conduct more stringent supervision of activities that occur within the company. Institutional investors are more active in buying and selling shares so they can increase the amount of information quickly which is reflected at the price level. The existence of shareholders such as institutional ownership has an important meaning in monitoring management. Institutional ownership such as insurance companies, banks, investment companies and ownership by other institutions will encourage increased optimal oversight. The monitoring mechanism will guarantee the increase of shareholders' prosperity. The significance of institutional ownership as a supervisory agent is emphasized through their sizable investment in the capital market. If the institution feels dissatisfied with managerial performance, then they will sell their shares to the market. Supervision mechanism can be done by placing a board of experts who are not financed by the company so that its position is not under the supervision of the manager. Thus, the expert board can carry out its functions effectively to control all the actions of managers. Another oversight that can be carried out is by providing input as material for consideration for managers in conducting business and through the General Meeting of Shareholders (GMS). Genis [7] states that Institutional Ownership has no influence on earnings management.
H3: There is an influence of Institutional Ownership with Earnings Management

\section{Relationship of Company Size to Profit Management}

The size of the company is basically a grouping of companies into several groups, including large, medium and small companies. Company scale is a measure used to reflect the size of the company based on total company assets [3]. Company size is the scale of the company as seen from the total assets of the company at the end of the year. Total sales can also be used to measure the size of the company [14]. The size of the company describes the size of the company. The size of the business in terms of business fields that are run. Determination of the size of the company can be determined based on total sales, total assets, average sales level [15]. Large companies have various advantages compared to small sized companies.

\section{Relationship between Leverage and Profit Management}

Leverage is the size of the company's assets financed by debt. The higher the leverage ratio indicates the higher the risk of the company's inability to pay its obligations [4]. According to Trisnawati [11] states that the leverage ratio describes the source of operating funds used by the company. The leverage ratio also shows the risks faced by the company. The greater the risk faced by the company, the uncertainty to generate profits in the future also increases. Companies that have high leverage ratios due to the large amount of debt compared to assets owned by the company, allegedly doing earnings management because the company is threatened by default, which is unable to meet debt obligations on time. Companies try to avoid it by making policies that can increase revenue and profits [11]. According to Antonia [4] a company with a high leverage ratio is suspected of doing earnings management. Earnings management is carried out to be able to provide better bargaining positions relating to external funding sources or when there is a Journal of Management Science and Research Volume 6, Number 2, February 2017 ISSN: 2461-05934 renegotiations if the company really cannot pay off its obligations. The level of earnings management of companies with high levels of debt leverage is relatively higher compared to low levels of debt leverage [21].

H5: There is an influence of Leverage with Profit Management

\section{CHAPTER III}

\section{RESEARCH METHODS Research Type}

The research approach used in this research is a quantitative research approach that is data in the form of numbers or numbers that are used to examine the population or a particular sample, the sampling technique is carried out randomly, data collection using research instruments, quantitative data analysis with the 
aim to test the hypothesis has been established [1]. It said quantitative research because this study aimed to provide empirical evidence about the effect of corporate governance, profitability (ROA), company size and leverage on earnings management. This study uses secondary data, namely data in the form of annual financial documents / reports of manufacturing companies listed on the Indonesia Stock Exchange in the 2014-2017 period, which are written data relating to research objects published by the company and the IDX.

\section{Operational Definition of Variables and Measurement of Variables}

This section explains the operational definitions of the variables used in this study. The dependent variable in this study is the activity of commissioner god, cash flow, institutional ownership, leverage and company size, which are independent variables. Each operational definition of the variable will be explained as follows:

\section{Independent Variable}

The independent variable used in this study is the independent variable is the variable that affects the dependent variable.

\section{Board of Commissioners Meeting}

The Board of Commissioners has two duties, namely supervising directors and giving advice to company directors. Commissioners are generally tasked with supervising the directors' policies in managing transportation and providing advice to directors, according to Article 108 of Law Number 40 Year 2007. The supervisory task can be a form of preventive or repressive supervision. Preventive supervision is to take action by keeping in advance that undesirable things will not happen that will harm the company, for example for some actions of directors that have to be requested by the commissioners for approval, whether they have been carried out or not. In this case, the commissioner must always monitor him. Whereas what is meant by repressive supervision is supervision intended to test the actions of the directors whether all the actions carried out do not cause harm to the company and do not conflict with the law and the articles of association.

\section{Free Cash Flow}

Free Cash Flow is the actual cash flow that is distributed to investors after the company has made all the investment and working capital needed to maintain its operational continuity. This variable is calculated using the Brigham and Houston formula [10], namely: Free Cash Flow = Operating Cash Flow - Capital Expenditures

\section{Institutional Ownership}

Institutional ownership generally acts as a party that monitors the company. This institutional ownership is usually the shares owned by other companies both inside and outside the country as well as domestic and foreign government shares [22]. Institutional shareholding will increase more optimal supervision of insider performance [13], which in turn will have an impact on increasing company profits, causing company value (PER) to increase as well. Mathematically institutional ownership can be formulated [3]:

\section{Company Size}

Riyanto [23], company size is the size of the company seen from the value of equity, sales value or asset value. The indicator used to measure the variable size of the company is the indicator proposed by Yogiyanto [24] the size of the assets used to measure the size of the company, the size of these assets is measured as a logarithm of total assets.

\section{Leverage}

Leverage is a company's ability to use funds that have a fixed burden or debt effectively so that it can obtain an optimal level of business income [7].

\section{Bound Variable (Dependent Variable)}

Earnings Management (Y) is carried out on an accrual basis. The use of this accrual basis according to Justrina [17] is caused by three things. First, accruals are the main product of generally accepted accounting principles and earnings management is easier to occur on accrual-based financial statements compared to cashbased ones. Second, by understanding the use of the accrual basis, it will be able to reduce the problems that arise in measuring the impact of various accounting methods on earnings. The impact arises as a result of deliberate choosing certain accounting methods to facilitate earnings engineering. These impacts can mislead users of financial statements even for managers as financial report makers. Third, companies generally prefer policies on an accrual basis using profit before tax. So, if investors cannot determine the existence of indications of earnings management on an accrual basis, then there is no earnings management on the company's financial statements and investors do not need to take into account the impacts arising from earnings management such as mistakes in investment. Detection of the possibility of doing earnings management in the financial statements is examined through the use of accruals. The amount of accruals reflected in the calculation of earnings consists of discretionary accruals and non-discretionary accruals. The dependent variable in this study is earnings management. Earnings management is a condition where management intervenes in the process of preparing financial statements for external parties so that it flattens, increases and decreases earnings reporting. Measurement of earnings management uses Discretionary Accrual (DA). 


\section{Population and Samples \\ Population}

Sugiyono [19] population is a generalization area consisting of: objects / subjects that have certain qualities and characteristics determined by researchers to be studied and then drawn conclusions. The population of this study is manufacturing companies listed on the IDX.

\section{Samples}

Sugiyono [19] sample is part of the number and characteristics possessed by the population. The sample of this study is a transportation company listed on the IDX. Reasons for researchers choosing transportation companies include: First, the development of transportation companies is quite rapid, as evidenced by the increasing number of types of drinks offered on the market, so the company will become more advanced and large which causes investors to invest their capital. Second, transportation companies have institutional investors who can monitor business agents to regulate profits so that the company is always well guarded. Third, a transportation company is a company that has an audit committee to regulate the company, so that people trust the company. The sample selection in this study is based on a purposive sampling method which is a non-random sampling technique for which information is obtained using certain considerations. The sample criteria that will be used are:

- Transportation companies listed on the Indonesia Stock Exchange for 2014 - 2017.

- Providing full annual reports and sustainability reports for 2014-2017.

- Companies that have complete data on the variables of Leverage, Corporate Governance, Free Cash Flow, Company Size and Institutional Ownership.

- During 2014 - 2017 companies must register.

Table 3.2

Population and Sample

Sample Criteria Number of Companies

Transportation companies listed on the Indonesia Stock Exchange (IDX) during the 2014-2017 research periods 34

Transportation companies that were delisted in 2014 2017 (4)

The total sample used in the study was 30

Total $(30 * 4) 120$

\section{DATA COLLECTION TECHNIQUES}

The method of data collection is the study of documentation by holding records and examining aspects or documents relating to the objects in this study. Financial Report Data and annual reports including samples were obtained from the IDX. Data collection is done by tracing the selected annual report into a sample.

\section{METHOD OF ANALYSIS \\ Descriptive Statistics}

Descriptive statistics are statistical tools that function to describe or provide an overview of the object under study through sample or population data as they are, without analyzing and making generally accepted conclusions from the data. Descriptive statistics are used to describe data that is seen from the mean, median, standard deviation, minimum value, and maximum value. This test is done to make it easier to understand the variables used in research [25]. Mean is used to find out the average of the relevant data. The standard deviation is used to find out how much the relevant data varies from the average. The maximum is used to find out the largest amount of data in question. The minimum is used to find out the smallest amount of data in question [25].

\section{Classical Assumption Test}

Before conducting a regression test first testing the classical assumptions Ghozali [15] states that multiple linear regression analysis needs to avoid deviations of classical assumptions so that problems do not arise in the use of the analysis. So that in the regression analysis obtained a regression model that can be accounted for.

\section{Normality test}

The normality test aims to test whether in the regression model the independent variable and the dependent variable or both are normally distributed or not. A good regression model is having normal or near normal data distribution. One of the easiest ways to see normality is to look at histograms and graphs. The basis for decision making is to use Kolmogrov-Smirnov (KS) non-parametric statistical analysis, with guidelines for making decision sig or significance or probability values $<0.05$, distribution is not normal, sig or significance value or probability value> 0.05 , distribution is normal $[15,12]$.

\section{Autocorrelation Test}

Autocorrelation test aims to test whether in a linear regression model there is a correlation between residuals in period $\mathrm{t}$ with residuals period $\mathrm{t}-1$ (previous). A good regression model is a regression that is free from autocorrelation. The method that can be used to detect the presence or absence of autocorrelation is the Durbin Watson (DW) test. Decision making for the presence or absence of autocorrelation [15]:

- That the DW value is located between the upper bound or upper bound (du) and (4-du), and then the autocorrelation coefficient equal to zero means that there is no positive autocorrelation.

- If the DW value is lower than the lower bound or lower bound (dl), then the autocorrelation coefficient is greater than zero means there is a positive autocorrelation. 
- If the DW value is greater than the lower bound or lower bound (4-dl), then the coefficient of autocorrelation is smaller than zero means there is a negative autocorrelation.

- If the DW value is located between the upper limit (du) and the lower limit (dl) or DW between (4-du) and (4-dl), then the results cannot be concluded.

\section{Heteroscedasticity Test}

Is homoscedasticity or heterocedasticity does not occur [15]. Scatter plot testing, regression models that do not occur heterokedasticity must meet the following requirements:

1. If there are certain patterns, such as the dots that form a regular pattern (wavy, widened and then narrowed), then it indicates that heteroscedasticity has occurred.

Heterokedastisitas test aims to test whether in the regression model there is an unequal variance from the residuals of one observation to another. If the variance from one observation residual to another observation is still called homoscedasticity, and if it is different is called heterocedasticity. A good model of regret

2. If there is no clear pattern and spread points above and below the number 0 on the $\mathrm{Y}$ axis, then heterokedasticity does not occur.

\section{Multicollinearity Test}

Multicollinearity test aims to test whether the regression model found a correlation between independent variables or not. A good model should not have a high correlation between independent variables. To detect the presence or absence of multicollinearity in the regression model can be known from the tolerance value and the value of the variance inflation factor (VIF). Tolerance measures the variability of selected independent variables that cannot be explained by other independent variables. So a low tolerance value is equal to a high VIF value (because VIF $=1 /$ tolerance) and indicates a high degree of colony. The cut-off value commonly used is a tolerance value of 0.10 or equal to VIF values above 10 [12].

\section{Multiple Regression Analysis}

This study tested the hypothesis using multiple regression analysis, because there were more than one independent variable. The purpose of this test is to examine the effect of several independent variables on the dependent variable with moderation variables. The multiple linear regression equation in this study is stated with the following equation:

$\mathrm{Y}=\mathrm{a}+\mathrm{b} 1 \mathrm{x} 1+\mathrm{b} 2 \mathrm{x} 2+\mathrm{b} 3 \mathrm{x} 3+\mathrm{b} 4 \mathrm{x} 4+\mathrm{b} 5 \mathrm{x} 5+\mathrm{e}$ Description:

$\mathrm{Y}=$ Discretionary Accrual (proxy for earnings management) $\mathrm{a}=$ constant

$\mathrm{X} 1=$ Board of Commissioners Meeting

$\mathrm{X} 2$ = Free Cash Flow

X3 = Institutional Ownership

$\mathrm{X} 4$ = Company Size

$\mathrm{X} 5=$ leverage

b1, b2, b3 = Regression Coefficient

$\mathrm{e}=$ error

\section{Coefficient of Determination (R2)}

The coefficient of determination (R2) shows the strength of a linear relationship between the dependent variable and the independent variable and explains how the direction of the relationship between the variables.

\section{Partial Test (T Test)}

$\mathrm{T}$ statistic test basically shows how far the influence of one independent variable individually in explaining the dependent variable. $\mathrm{T}$ test has a significance value $\alpha=5 \%$. Criteria for testing hypotheses using the statistical test $t$ is if the significance value of $\mathrm{t}$ ( $\mathrm{p}$-value) $<0.05$ then an alternative hypothesis is accepted, which states that an independent variable individually and significance affects the dependent variable.

\section{Model Conformity Test (F Test)}

F statistical test aims to determine the feasibility of multiple regression models, whether the effect is significant or not, the significance level used is 0.05 . If the probability of $F$ is less than 0.05 then the regression model can be used to predict the independent variable or in other words the dependent variable simultaneously influences the dependent variable. Conversely, if the probability value $\mathrm{F}$ is greater than 0.05 then the regression model cannot be used to predict the dependent variable or in other words the independent variable simultaneously does not affect the dependent variable.

\section{Chapter IV \\ RESULTS AND DISCUSSION \\ Descriptive Research Object \\ Overview of Research Objects}

The sample of this study is a transportation company listed on the IDX. Reasons for researchers choosing transportation companies include: First, the development of transportation companies is quite rapid, as evidenced by the increasing number of types of drinks offered on the market, so companies will become more advanced and large which causes investors to invest their capital. Second, transportation companies have Institutional investors which can monitor business agents to regulate profits so that the company is always well guarded. Third, a transportation company is a company that has an audit committee to regulate the company, so that people trust the company. 


\section{Place and Time of Research}

The population in this study is transportation companies that have been listed on the Indonesia Stock Exchange. Transportation companies that are used as samples are transportation companies that have been registered and have financial reports from 2014 to 2017.

\section{Characteristics of Respondents METHOD OF ANALYSIS Descriptive Statistics Test}

Descriptive statistics in this study are presented to provide information about the characteristics of the research variables including minimum, maximum, mean, and standard deviation and variance values.

Tabel-4.1: Hasil Statistik Deskriptif

\begin{tabular}{|l|c|r|r|r|r|r|}
\hline \multicolumn{7}{|c|}{ Descriptive Statistics } \\
\hline & $\mathrm{N}$ & $\begin{array}{c}\text { Minimu } \\
\mathrm{m}\end{array}$ & $\begin{array}{c}\text { Maximu } \\
\mathrm{m}\end{array}$ & \multicolumn{1}{c|}{ Mean } & $\begin{array}{c}\text { Std. } \\
\text { Deviation }\end{array}$ & Variance \\
\hline $\begin{array}{l}\text { Manajemen_L } \\
\text { aba }\end{array}$ & 105 & -.389 & .56 & .12 & .13 & .019 \\
\hline RD_Komisaris & 105 & 2.00 & 19.00 & 6.29 & 3.4 & 12.15 \\
\hline FCF & 105 & 6388.00 & 96.59 & 98.56 & 20.91 & 42.00 \\
\hline Kepemilikan & 105 & .19 & .8600 & .51 & .20 & .043 \\
\hline Leverage & 105 & .00 & 8.31 & .75 & 1.08 & 1.183 \\
\hline Ukuran & 105 & 15.78 & 31.51 & 26.12 & 3.59 & 12.957 \\
\hline & & & & & & \\
\hline
\end{tabular}

(Sumber : Data diolah dengan SPSS 23)

a. N: 105 explains that the data processed in this study

b. The earnings management variable has a minimum value of -0.389 , a maximum value of 0.56 , a mean of 0.12 , a standard deviation of 0.13 and a variance of 0.019 .

c. The commission variable has a minimum value of 2.00 , a maximum value of 19.0 , a mean of 6.29 , a standard deviation of 3.48 and a variance of 12.15 .

$\mathrm{d}$. The free cash flow variable has a minimum value of 6388.00, a maximum value of 96.59 , a mean of 98.56, a standard deviation of 20.90 and a variance of 42.00 .

e. Institutional ownership has a minimum value of 0.19 , a maximum value of 0.86 , a mean of 0.51 , a standard deviation of 0.20 and a variance of 0.43 .

f. The leverage variable has a minimum value of 0.00 , a maximum value of 8.31 , a mean of 0.75 , a standard deviation of 1.08 and a variance of 1.18 .

2. Classical Assumption Test

2.1. Normality test

Test for normality using One Sample Kolmogorov Smirnov. With the following hypothesis testing:

1) Zero Hypotheses (Ho): Data is normally distributed

2) Alternative Hypothesis (Ha): Data is not normally distributed

The results of normality testing in this study can be seen in table 4.2 as follows:
Table-4.2: Kolmogorov-Smirnov One Sample Normality Test

\begin{tabular}{|c|c|c|}
\hline \multicolumn{3}{|c|}{ One-Sample Kolmogorov-Smirnov Test } \\
\hline & & $\begin{array}{c}\text { Unstandardize } \\
\text { d Residual }\end{array}$ \\
\hline \multicolumn{2}{|l|}{$\mathrm{N}$} & 105 \\
\hline \multirow{2}{*}{$\begin{array}{l}\text { Normal } \\
\text { Parameters }\end{array}$} & Mean & .000 \\
\hline & $\begin{array}{l}\text { Std. } \\
\text { Deviation }\end{array}$ & .130 \\
\hline \multirow{3}{*}{$\begin{array}{l}\text { Most Extreme } \\
\text { Differences }\end{array}$} & Absolute & .078 \\
\hline & Positive & .078 \\
\hline & Negative & -.075 \\
\hline \multicolumn{2}{|l|}{ Test Statistic } & .078 \\
\hline \multicolumn{2}{|c|}{ Asymp. Sig. (2-tailed) } & .118 \\
\hline
\end{tabular}

The test results above show a residual value of 0.200 or a significance value above 0.05 then the Ho hypothesis is accepted or the residual value of taxpayer compliance is normally distributed.

\section{Autocorrelation Test}

Autocorrelation test aims to test whether in a linear regression model there is a correlation between residuals in period $\mathrm{t}$ with residuals period $\mathrm{t}-1$ (previous). A good regression model is a regression that is free from autocorrelation.

Table-4.3: Autocorrelation Test Results Model Summaryb

\begin{tabular}{|l|c|c|c|c|c|}
\hline Model & $\mathbf{R}$ & $\begin{array}{c}\mathbf{R} \\
\text { Square }\end{array}$ & $\begin{array}{c}\text { Adjusted } \\
\text { R Square }\end{array}$ & $\begin{array}{c}\text { Std. Error of } \\
\text { the Estimate }\end{array}$ & $\begin{array}{c}\text { Durbin- } \\
\text { Watson }\end{array}$ \\
\hline 1 & $.353^{\text {a }}$ & .125 & .081 & .1338645790 & 2.114 \\
\hline \multicolumn{2}{|l}{ a. Predictors: (Constant), Ukuran_Perusahaan, Kepemilikan_institusional, } \\
RD_Komisaris, FCF, Leverage \\
\hline
\end{tabular}

(Sumber: Data diolah dengan SPPS 23) 
a. Predictors: (Constant), Company Size, Institutional Ownership, Commissioner Commissioner, FCF, Leverage

b. Dependent Variable: Management_Laba

(Source: Data processed with SPPS 23)

$\mathrm{DW}=2.114, \mathrm{~K}=5 \mathrm{DL}=1.5837, \mathrm{~N}=105 \mathrm{DU}=$ $1.7827,4-\mathrm{DU}=2.2173, \mathrm{DU}<\mathrm{DW}<4 \mathrm{DU}=$ no symptoms of autocorrelation, $1.7827<2.114<2.2173$ > there is no autocorrelation

\section{Heteroskedacity Test}

Heteroskedacity test aims to test whether in the regression model there is a variance in variance from one observation variable to another observation. If the variance from one observation residual to another observation remains. In this test heterokedasticity testing was detected by glacial test. If there are independent variables that have a significant influence on the significance level of 0.05 on absolute residuals, heterokedasticity occurs in the regression model.

Table-4.4: Heteroskedacity Test Result

\begin{tabular}{|c|c|c|c|}
\hline \multicolumn{4}{|c|}{ Coefficients $^{\mathrm{a}}$} \\
\hline \multicolumn{2}{|c|}{ Model } & $\mathbf{t}$ & Sig. \\
\hline \multirow[t]{6}{*}{1} & (Constant) & 2.980 & .004 \\
\hline & RD_Komisaris & -.778 & .438 \\
\hline & FCF & .805 & .423 \\
\hline & Kepemilikan_institusional & -.458 & .648 \\
\hline & Leverage & 1.566 & .121 \\
\hline & Ukuran_Perusahaan & -1.677 & .097 \\
\hline \multicolumn{4}{|c|}{ a. Dependent Variable: RES2 } \\
\hline
\end{tabular}

a. Dependent Variable: RES2

(Source: Data processed with SPPS 23)

From table 4.4 it can be seen that the significance value of each variable is more than 0.05 , so it can be concluded that there is no problem in heroskedacity.

\section{Multicollinearity Test}

This multicollinearity test aims to test whether the regression model found a correlation between independent variables. In this study multicollinearity testing is seen from the value of VIF (Variance Inflation Factor) and tolerance value. If the tolerance value is more than 0.10 and the VIF value is less than 10.00 then there is no multicollinearity.

Tabel-4.5: Hasil Uji Multikolinearitas

\begin{tabular}{|c|c|c|c|c|c|}
\hline \multicolumn{6}{|c|}{ Coefficients $^{\mathrm{a}}$} \\
\hline \multirow{2}{*}{\multicolumn{2}{|c|}{ Model }} & \multirow[t]{2}{*}{$\mathrm{t}$} & \multirow[t]{2}{*}{ Sig. } & \multicolumn{2}{|c|}{ Collinearity Statistics } \\
\hline & & & & Tolerance & VIF \\
\hline \multirow[t]{6}{*}{1} & (Constant) & 2.770 & .007 & & \\
\hline & RD_Komisaris & -1.026 & .307 & .964 & 1.037 \\
\hline & FCF & -.935 & .352 & .920 & 1.087 \\
\hline & Kepemilikan_institusional & 1.928 & .057 & .981 & 1.019 \\
\hline & Leverage & 1.068 & .288 & .900 & 1.111 \\
\hline & Ukuran_Perusahaan & -2.203 & .030 & .930 & 1.076 \\
\hline
\end{tabular}

(Sumber : Data diolah dengan SPPS 23)

From the table above it can be seen that the tolerance value of all independent variables is more than 0.10 . VIF calculation results also show that there is no single independent variable that has a VIF value of more than 10.00 . It can be concluded that there is no multicollinearity between independent variables in the regression model.

\section{RESULTS OF MULTIPLE REGRESSION ANALYSIS}

Linear regression test is to find a picture of the effect of the independent variables on the dependent variable. This study uses multiple linear regression analysis because it has more than one independent variable. The results of multiple linear regression analysis in this study, can be seen from the table below: 
Tabel-4.6: Hasil Uji Regresi Berganda

\begin{tabular}{|c|l|c|c|}
\hline \multicolumn{2}{|c|}{ Coefficients $^{\text {a }}$ Model } & \multicolumn{2}{c|}{ Unstandardized Coefficients } \\
\cline { 3 - 4 } \multicolumn{2}{|c|}{1} & B & Std. Error \\
\cline { 2 - 4 } & (Constant) & .300 & .108 \\
\cline { 2 - 4 } & RD_Komisaris & -.004 & .004 \\
\cline { 2 - 4 } & FCF & -6.180 & .000 \\
\cline { 2 - 4 } & Kepemilikan_institusional & .124 & .064 \\
\cline { 2 - 4 } & Leverage & .014 & .013 \\
\cline { 2 - 4 } & Ukuran_Perusahaan & -.008 & .004 \\
\hline \multicolumn{2}{|l|}{ a. Dependent Variable: Manajemen_Laba } \\
\hline
\end{tabular}

(Sumber : Data diolah dengan SPPS 23)

Based on table 4.6 the regression equation that can be formulated is as follows:

$\mathrm{Y}=\mathrm{a}+\mathrm{b} 1 \mathrm{x} 1+\mathrm{b} 2 \mathrm{x} 2+\mathrm{b} 3 \mathrm{x} 3+\mathrm{b} 4 \mathrm{x} 4+\mathrm{b} 5 \mathrm{x} 5+\mathrm{c}$

$\mathrm{EM}=0,300+(0,004)+(6,1800)+0,124+0,014+$ $(0,008)+\mathrm{e}$

From the results of testing the significance of the data, the results obtained include

a) From the calculation above the constant of 0.300 this shows that if the variable commissioners, free cash flow, institutional ownership, leverage and company size are considered constant, and then the magnitude of the dependent variable earnings management is 0.300 .

b) Commissioner variable has a coefficient value of -0.004 with a negative direction, this shows that if the commissioner variable decreases by $1 \%$ will cause a decrease in the value of earning management received worth the coefficient.

c) The variable free cash flow has a coefficient value of -0.6180 with a negative direction, this shows that if the free cash flow variable drops by $1 \%$ will cause an increase in the value of earning management received worth the coefficient. d) Institutional variables have a coefficient value of 0.124 with a positive direction, this shows that if the institutional variable rises $1 \%$ will cause an increase in the value of earning management received worth the coefficient.

e) The variable leverage has a coefficient value of 0.014 with a positive direction, this shows that if the variable leverage increases $1 \%$ will cause an increase in the value of earnings management received coefficient.

f) Variable size of the company has a coefficient of -0.008 with a negative direction; this shows that if the company's size variable drops $1 \%$ will cause a decrease in the value of earning management received worth the coefficient.

\section{HYPOTHESIS TEST RESULTS}

Significant Test of Individual Parameters (T Test)

$\mathrm{T}$ test (T-test) aims to show how far the influence of an independent variable with the dependent variable individually individually in explaining the dependent variable and to show how far the influence of one independent variable is moderated to the dependent variable with a significance level of $5 \%$.

Tabel-4.7: Hasil Uji Signifikan Parameter Individual (Uji T)

\begin{tabular}{|c|c|c|c|}
\hline \multicolumn{4}{|c|}{ Coefficients $^{\mathrm{a}}$} \\
\hline \multicolumn{2}{|c|}{ Model } & $\mathrm{T}$ & Sig. \\
\hline \multirow[t]{6}{*}{1} & (Constant) & 2.770 & .007 \\
\hline & RD_Komisaris & -1.026 & .307 \\
\hline & FCF & -.935 & .352 \\
\hline & Kepemilikan_institusional & 1.928 & .057 \\
\hline & Leverage & 1.068 & .288 \\
\hline & Ukuran_Perusahaan & -2.203 & .030 \\
\hline \multicolumn{4}{|c|}{ a. Dependent Variable: Manajemen_Laba } \\
\hline
\end{tabular}

(Sumber : Data diolah dengan SPPS 23)

\section{Model Conformity Test (F Test)}

Model suitability test (Test F) is used to indicate whether all independent variables included in the model have an influence together on the dependent variable. If the analysis using the $\mathrm{F}$ test shows that all independent variables simultaneously are a significant explanation of the dependent variable. A thorough test or $\mathrm{F}$ test is performed to determine that the independent variable simultaneously has a significant effect on the dependent variable of corporate taxpayer compliance. 
Following are the results of testing the suitability of the model (Test F) as follows:

Tabel-4.8: Hasil Uji Kesesuaian Model (Uji F)

\begin{tabular}{|l|l|l|l|}
\hline \multicolumn{4}{|c|}{ ANOVA $^{\mathbf{a}}$} \\
\hline \multicolumn{2}{|c|}{ Model } & F & Sig. \\
\hline \multirow{3}{*}{1} & Regression & 2.828 & $.020^{\mathrm{b}}$ \\
\cline { 2 - 4 } & Residual & & \\
\cline { 2 - 4 } & Total & & \\
\hline
\end{tabular}

(Sumbe: Data diolah dengan SPPS 23)
Based on table 4.8 it is known that the results of the simultaneous test (Test F) show that the significance value indicates 0.020 . If the significance value $<0.05$ then the independent variables together have a significant effect on the dependent variable.

\section{Determination Coefficient Test}

The coefficient of determination (R2) is used to measure how far the model's ability to explain the independent variables. The following are the results of testing the coefficient of determination:

Tabel-4.9: Hasil Uji Koefisien Determinasi $\left(\mathbf{R}^{2}\right)$

\begin{tabular}{|l|c|c|c|}
\hline Model & $\mathbf{R}$ & R Square & Std. Error of the Estimate \\
\hline 1 & $.286^{\mathrm{a}}$ & .082 & .08799 \\
\hline \multicolumn{3}{|c|}{ a. Predictors: (Constant), Ukuran_Perusahaan, } \\
Kepemilikan_institusional, RD_Komisaris, FCF, Leverage \\
\hline \multicolumn{2}{|l}{ b. Dependent Variable: RES2 } \\
\hline
\end{tabular}

(Sumber: Data diolah dengan SPPS 23)

Based on table 4.9 it is known that the coefficient of determination (R2) of the Adjusted R Square of $82 \%$ while the remaining $18 \%$ is explained by variables outside the model with a standard error rate of $8 \%$.

\section{DISCUSSION}

a) Relationship between the Board of Commissioners' Activities and Profit Management Based on Law No. 40 of 2007 concerning Transportation Companies, the board of commissioners is the party in charge of supervising the management policy, the management process in general, and giving advice to directors. Fama and Jensen [24] stated that non-executive directors (independent commissioners) can act to oversee management policies and provide direction to management. An independent commissioner is the best position to carry out the monitoring function in order to create a company with good corporate governance. In general, independent boards of commissioners have better supervision of managers so that they are able to influence the possibility of irregularities by managers. This is consistent with the opinion of Jensen and Meckling [22] which states that agency theory supports the statement that to increase the independence of the board, the board must be dominated by parties from outside the company (outsider). Some opinions state that nonexecutive directors are needed to control and supervise management behavior that acts opportunistic. The results of Chtourou, Bedard and Chtourou's [26] research in Antonia [21] show that the greater the proportion of the external board of commissioners, the smaller the earnings management. This shows that the proportion of the board of commissioners negatively affects earnings management.

\section{b) Relationship of Free Cash Flow to Profit Management}

According to Reina [27] free cash flows towards earnings management are proven. These results indicate that the lower the free cash flows the higher the earnings management. When profits show that the greater profits are created by management through its accrual policy, especially through earnings aggressiveness policies. In other words, companies that have large free cash flows will tend to report lower earnings. The results of this study are consistent with previous research which shows that free cash flow has a negative effect on earnings management.

\section{c) Relationship of Institutional Ownership to Profit Management}

Based on the results of statistical data processing, it can be seen that there is a significant influence of the variable Institutional Ownership. This is evidenced by a probability greater than the significance value. The results of testing the first hypothesis which says that institutional ownership affects earnings management. Where the amount of share ownership owned by an institution affects the actions of managers in carrying out earnings management practices. This means that when the number of shares owned by the institution increases, this will lead to an indication of earnings management practices. The results of this study are not in line with Agency theory where institutional investors are parties who can monitor agents with large holdings, thus motivating managers to manage earnings. But based on the results of the panel data test shows the influence of the level of institutional ownership in a positive direction. Where appropriate, institutional investors can monitor management actions to reduce earnings management practices. 
Aisyah \& Wiwik Utami; Saudi J Bus Manag Stud, Feb., 2020; 5(2): 118-131

d) Relationship of Leverage against Profit Management

Leverage is the degree to which securities with debt are used in a company's capital structure. Financial leverage must be analyzed to see how well the funds are handled. The mix of short-term and long-term funds obtained from outside must be in accordance with the objectives and company policies. If the handling of these funds is not done properly, the company's financial leverage can trigger management to make earnings management. Based on the results of SPSS analysis shows that leverage has no effect on earnings management, but shows a positive number, meaning that the higher the company's financial leverage, the higher the earnings management action will be. This means that the company has a high debt and to cover all risks that occur due to high debt, the company tends to do earnings management with Debt Covenant Hypothesis, namely the higher the debt / equity of the company, meaning that the company is getting closer to the limits that are there is a debt agreement and the greater the opportunity for breach of the agreement and the cost of technical failure, the greater the possibility of managers using accounting methods that can increase profits. The results of this study reject research conducted by [4] which shows that leverage has a significant effect on earnings management.

\section{e) Relationship of Company Size to Profit Management}

Company size is a scale in which companies can be classified according to various ways, including total assets, log size, sales and stock market value [12]. The larger the size of the company, the smaller the earnings management by management, while the smaller the size of the company, the greater the earnings management by management [14]. Lee \& Choi [3] states that small companies are more likely to manage earnings than large companies. Based on the description above, the hypothesis is proposed as follows:

\section{Chapter V}

\section{CONCLUSIONSAND RECOMMENDATIONS Conclusion}

This research was conducted with the aim to determine the effect of board of commissioners' meetings, free cash flow, institutional ownership, and leverage and company size on earnings management in transportation companies. Based on the formulation of the problem, testing the hypothesis and the discussion presented in the previous chapter, the following conclusions can be drawn:

- The activity of the board of commissioners with the proxy of the board of commissioners meeting does not affect earnings management; this is because the commissioners do not have full rights to earnings management.

- Free cash flow has no effect on earnings management; this is because the use of cash flow reports cannot be used as the main reference in terms of carrying out corporate earnings management.

- Institutional ownership has no effect on earnings management; this is because institutional ownership cannot give unilateral decisions in determining earnings management.

- Leverage has no effect on earnings management; this is because corporate leverage reports reported to shareholders must be transparent for the purpose of dividend distribution.

- The size of the company affects earnings management; this is because companies with relatively large size will be seen by the public's performance so that the company will report its financial condition with more caution, more informative and more transparent. Therefore, fewer companies do earnings management practices.

\section{SUGGESTIONS}

As previously explained that this study contains limitations. But the results of this study can motivate further research. By considering the existing limitations, it is hoped that future research will improve the following factors:

- Further research is suggested to be able to expand the object of research, not only to focus on transportation companies. But it can add other research objects listed on the Indonesia Stock Exchange (IDX) so that research can be generalized.

- Future studies are recommended to use other variables besides the variables in this study.

\section{REFERENCES}

1. Sugiyono. (2005). "Metode Penelitian Bisnis", Bandung: Alfabeta.

2. Sulistyanto, H. Sri, dan, H.W.(2003). "Good Corporate Governance: Berhasilkah Diterapkan di Indonesia, Behavior Accounting, 23 0ktober.

3. Wahidahwati. (2002). "Kepemilikan Manajerial dan Agency Conflict: Analisis Persamaan Simultan Non Linier dari Kepemilikan Manajerial", Penerimaan Resiko (Risk Taking), Kebijakan Utang dan Kebijakan Dividen, SNA V, September.

4. Fahmi, I. (2013). Perilaku Organisasi Teori, Aplikasi, dan Kasus. Bandung: Alfabeta.

5. Kangarluei, S.J., Morteza, M., \& Taher, A. (2011). The Investigation and

6. Don, V. (2007). "Pengaruh Penerapan Mekanisme Good Corporate Governance Terhadap Integritas Laporan keuangan”. Skripsi Ekonomi Jurusan Akuntansi Universitas Padjadjaran (tidak dipublikasikan) Bandung.

7. Agia, L.N.(2015). "Evaluasi Penerapan Sistem Pengukuran Dan Pelaporan Kinerja", (Studi Kasus Pada Dinas Pendidikan Provinsi Riau).

8. Dewan Standar Akuntansi Keuangan Ikatan Akuntansi Indonesia. (2004). "Standar Akuntansi 
Keuangan, per 1 April 2004”, Jakarta : Salemba Emapat.

9. Umi, N.(2007). "Riset Manajemen Sumber Daya Manusia", Agung Media, Jakarta, 2007. www. governance-indonesia.com

10. Brigham, dan H. (2010). "Dasar-dasar Manajemen Keuangan Buku 1 (Edisi 11)", Jakarta: Salemba Empat, 2010.

11. Agoes, Sukrisno, dan, T., Estralita. (2009). "Akuntansi Perpajakan, Edisi 2", Jakarta: Salemba Empat, 2009.

12. Horne, James, C. (2012). Van dan John M Wachowicz, Jr., "Prinsip-prinsip Manajemen Keuangan (Edisi 13)", Jakarta: Salemba Empat.

13. Moh,Wahyudin, Z.(2008). "Good Corporate Governance", Bandung: Alfabeta.

14. Veronica, S., dan, Siddharta, U. (2005). "Pengaruh Struktur Kepemilikan, Ukuran Perusahaan, dan Praktek Corporate Governance terhadap Pengelolaan Laba (Earnings Management)", Artikel yang Dipresentasikan pada Simposium Nasional Akuntansi 8 Solo.

15. Ghozali, I. (2011). “Aplikasi Analisis Multivariate dengan Program SPSS", Semarang: Badan Penerbit Universitas Diponegoro.

16. Andi, S. (2006). "Statistika Untuk Ekonomi dan Bisnis", Bandung : Pustaka.

17. Law, J. (2016). "Perspective on School Guidance Counselling", Alberta Counsellor, 29(2): 6. Retrieved January 11, 2016 (http://e-resources. perpusnas.go.id/library.php?id=00001).

18. Badan, P., dan, Pembangunan, K. (BPKP). (2000). Akuntabilitas dan Good Corporate Governance. Jakarta: Lembaga Administrasi Negara.

19. Sugiyono. (2008). "Metode Penelitian Kuantitatif, Kualitatif, dan $R \& D$ ”, Alfabeta, Bandung.
20. Chen, T. (2010). "Analysis on accrual-based models in detecting earnings Management", Lingnan Journal of Banking, Finance and Economics; 2(5).

21. Antonia, E. (2008). "Analisis Pengaruh Reputasi Auditor, Proporsi Dewan Komisaris Independen, Leverage, Kepemilikan Manajerial dan Proporsi Komite Audit Independen Terhadap Manajemen Laba". Tesis: Program Studi Magister Manajemen Program Pasca Sarjana Universitas Diponegoro Semarang.

22. Susiana, A.H. (2007). “Analisis Pengaruh Indepedensi, Mekanisme Corporate Governance, dan Kualitas Audit Terhadap Integritas Laporan Keuangan", Simposium Nasional Akuntansi X.

23. Jumingan.(2008). "Analisis Laporan Keuangan", Jakarta : Bumi Aksara.

24. Sedarmayanti. (2007). "Good Governance dan Good Corporate Governance", Bandung: Mandar Maju.

25. Ningsaptiti, R.(2010). "Pengaruh ukuran Perusahaan dan Corporate Governance terhadap Manajemen Laba pada Perusahaan Manufaktur yang Terdaftar Di BEI'. Skripsi. Universitas Diponegoro. Semarang.

26. Zaki, B.(2004). "Intermediate Accounting", Yogyakarta: BPFE Yogyakarta, 2004

27. Exchange (Tse). With An Emphasis On Earnings Management. Int. Journal of Eco-nomics and Business Modeling, 2(2), 118-1123.

28. Jonathan, S. (2006). Panduan Cepat dan Mudah SPSS 14. Andi, Yogyakarta. Comparison of Free Cash Flows In The Firms Listed In Tehran Stock.

29. Tesis.(2008). Program Magister Akuntansi Universitas Gadjah Mada. Yogyakarta, 2008. (tidak dipublikasikan).www. sinarharapan.co.id 